\title{
CONSUMER ENVIRONMENT RESPONSIBILITY AND CONCERN ON GREEN CONSUMPTION: UNAVAILABILITY OF ECO-PRODUCT MODERATION
}

\author{
Dandy Marcelino ${ }^{1}$, Teguh Widodo ${ }^{2}$ \\ 1'marceldandy@student.telkomuniversity.ac.id \\ Telkom University \\ Jl. Telekomunikasi Terusan Buah Batu Street, Bandung, Indonesia, 40257
}

received: 3/6/21; revised: 9/9/21; approved: 20/12/21

\begin{abstract}
Since the emergence of negative issues about the environment, caused human awareness level began to emerge. The green lifestyle is now starting widely applied by the people. The purpose of this study is to build a research framework, which helps companies to generate green consumption intention through the predictors of environmental responsibility mediated by environmental concern and moderated by green product unavailability. This research is classified as quantitative that used associative design with case study approach on Nutrifood company. The research model used is Structural Equation Modeling with questionnaire survey method to compile data from 269 people who know and have looked for Nutrifood products in Indonesia. The findings of this study reveals that environment concern is an important precursor and intermediary that helps encourage green consumption intention through consumer environment responsibility. The green products unavailability has moderating role between environment responsibility and green consumption intentions.
\end{abstract}

Keywords: consumer environment responsibility; green consumption intention; green purchase; intention; green product unavailability; green marketing; environmental friendly product

\section{INTRODUCTION}

Since the last few years, global warming has always been controversial and has changed the pace the climate that affects all life on Earth. According to data from the (Copernicus Climate Change Service, 2021), September 2020 was the hottest month in which the Earth's average temperature increased 0.05 degrees Celsius warmer than the previous record that occurred in September 2019. Meanwhile, in the nine months that have been running in 2020, three of them breaking the record for the hottest average temperature. These results show a dangerous trend of increasing temperatures will damage the Earth.

Indonesia ranks as the world's second-largest supplier of plastic garbage in the world with a waste volume of 187.2 million tons per year. Indonesia is the second-largest source of plastic trash in the oceans, after China. (Jambeck et al., 2015). In fact, one of the main pollution factors that still plague the Indonesian people is plastic waste, which has become a kind of hazardous waste that is difficult to dispose of, and it takes decades or hundreds of years to decompose. Currently, plastic waste is becoming an environmental issue that is increasingly being discussed by people from various sectors, including the consumer goods industry. It is undeniable that food and beverage products produced by the consumer goods industry have their own impact on the environment. Starting from the packaging which is mostly made of plastic material, to the waste its use has such a big impact on the environment. Repose on this phenomena, it would subsequently as a result of a rise in the number of businesses adopting the Green Company program in Indonesia, it attempts to decrease energy consumption and waste in the manufacturing process.

Many companies around the world have embarked on a journey of continuous improvement by using the word green to implement all management practices and improving the company performance (Zokaei et al., 2013). Green company is a business facing positive pressures to be environmentally efficient and contribute to their higher profitability (Moravcikova et al., 2017).

The development of production and consumption of green products has become a global trend where environmentally friendly behavior is becoming more prevalent, consumers will eventually change their buying 
behavior to be more open to green products, where environmental issues are used as consumer considerations in contributing to the global environment (Y. S. Chen et al., 2015). Meanwhile, according to (Shabani et al., 2013), environmentally friendly consumers refer to consumers who care about the environment in their buying behavior, and consumption habits and consideration of the impact on the environment around them.

The company which implements green marketing strategies in its activity business is Nutrifood which recently won an award as one of the Indonesia Green Companies 2018 by SWA Magazine in seventh place. Nutrifood Company is the only company engaged in the food and beverage industry that has succeeded becoming Indonesia Green Companies 2018.

To become a sustainable company, Nutrifood Company innovates its business strategy by realized through a sustainable 4R (Reduce, Reuse, Recycle, Replace) program which aims to minimize and reduce production waste. In addition, Nutrifood uses environmentally friendly ingredients in its production and carries out environmental conservation activities through the protection of natural resources. Employee education is also carried out as an effort to provide knowledge about an environmentally friendly lifestyle (Pambudi, 2018).

Therefore, Nutrifood sets aside $5 \%$ of its profit for environmental conservation funding activities through its Corporate Social Responsibility program. The environmental conservation program carried out by Nutrifood includes community empowerment by providing education by processing plastic waste produced from food wrappers which then produces goods that have economic value. Nutrifood has also implemented a take back system for its plastic waste products obtained from its consumers and has succeeded in recycling $526 \mathrm{~kg}$ of plastic waste.

Nutrifood acknowledged the growth in sales of supplement segment products in the midst of the Covid-19 pandemic. However, when viewed as a whole, sales data from Nutrifood company products show stagnant sales in the last few months from 2020 to 2021 as shown in Figure 1 (Apollo, 2021).

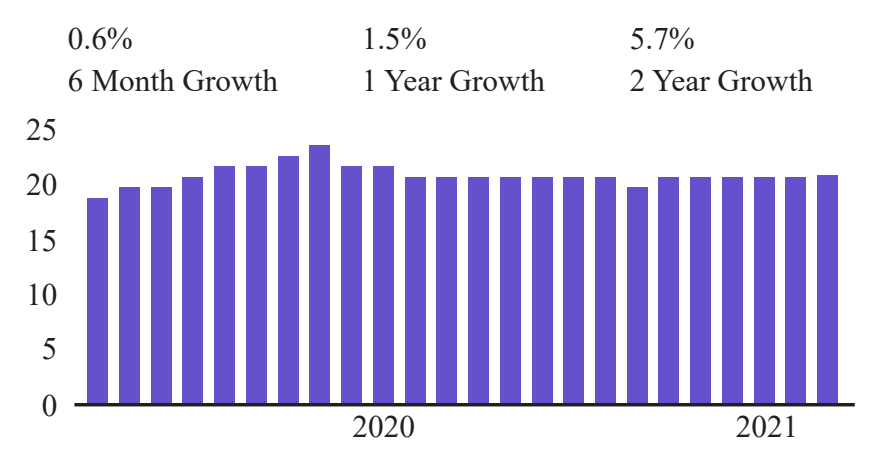

Figure 1. Nutrifood Product Sales Data for April 2019-March 2021

Previous research conducted by many researchers, scholars, and academics has looked at the effect of proenvironmental behavior on green consumption through the TPB (theory of planned behavior) (Ogiemwonyi et al., 2019). TPB evolved from the theory of reasoned action which a popular tool for analyzing individual behaviour outcomes (Shi et al., 2017; Wang et al., 2016). Therefore, consumers are more likely to acquire green consumption intentions if they have a good attitude toward green items (Ru et al., 2018). In the context of consumer behavior studies, have been shown to encourage individuals to exhibit green buying and consumption behaviors (Zhou et al., 2013). Therefore, it can be concluded when consumers have strong level of environment responsibility and there are no barriers in purchasing environmentally friendly products (Lutfie \& Marcelino, 2020). They'll be more inclined to set green consumption (purchasing) intention (Yen et al., 2017).

Recently, many researchers have used the theory of planned behavior to examine and observe various environmental behavioral outcomes. For example, (C. C. Chen et al., 2018) note that TPB is a useful framework for describing consumer intentions towards recycling. (Klöckner et al., 2013) suggested the TPB as a valid theory to predict and explain consumer desire to buy environmentally friendly products. In addition, the TPB model had been applied successfully in various contexts to study green consumption behaviour and has also been validated in studies of factors that influence green consumption (purchase) intention (A. Chen \& Peng, 2012; M. F. Chen \& Tung, 2014; Zhou et al., 2013).

This research establishes a research methodology that aids businesses in generating new ideas about green purchase (consumption) intentions of companies through predictors, namely environment responsibility mediated by environment concern and moderated by green product unavailability. The increasing concern for the environment has led to the conceptualization of the "environmental sustainability" term (Ogiemwonyi et al., 2019). Various businesses and organizations are now embedding sustainable practices into their business models with a particular focus on the environmental domain in their marketing efforts (Kautish et al., 2019). One of the main aspects of environmental sustainability is the concept of green consumption (Awuni et al., 
2016). Green consumption has been referred as a purchase behavior that includes a certain level of individual responsibility towards the environment and nature and has attracted the attention of many consumers (C. C. Chen et al., 2018). The purchase and consumption of environmentally beneficial green items has been branded as an effective strategy to curb the adverse effects of environmental degradation (Alam et al., 2019).

Environment responsibility has become an area of interest for academics and organizations with respect to influence on consumers' buying intentions and behavior (Slavoljub et al., 2015). The previous study perfomed by (Sadachar et al., 2016; Slavoljub et al., 2015; White \& Simpson, 2013; Yue et al., 2020) assume that there was a substantial impact of environment responsibility on green consumption intention and environment concerns. Previous studies point to the fact that consumers tend to show a constructive attitude towards protecting the environment around them (Ting \& Cheng, 2017). With the increasing awareness of consumers about the environment, consumer preferences for different products have changed (Zheng \& Chi, 2015). In fact, many studies have determined that consumers have expressed their desire to buy green products (Sreen et al., 2018). Consumers are now more driven to products that are more environmentally friendly (Ogiemwonyi et al., 2019).

Consumers with environment concerns who are worried about the environment are more inclined to purchase green items than those who are not (Dagher et al., 2015). If we look at the previous research findings conducted by (Dagher et al., 2015; Khaola et al., 2014; Marcelino, 2020; Nilasari \& Kusumadewi, 2016; Sreen et al., 2018; Zheng \& Chi, 2015 ) show that the environment concern variable has a favorable impact on the intention to buy green product. As for the findings of research conducted by (Rahimah et al., 2018; Yue et al., 2020), the environment concern variable is able to mediate the positive influence of environment responsibility on green consumption intention.

Environment concern has been identified as a key factor influencing green consumption (purchase) intention (Hojnik et al., 2019; Rahimah et al., 2018; Ting \& Cheng, 2017). There is limited literature available to explore the degree to which environmental concern and green consumption intentions are linked (Yue et al., 2020). It remains to be seen whether the influence of these constructs are influenced through other constructs (Ogiemwonyi et al., 2019).

The existing studies mainly only explain the issues of environment responsibility, environment concern, and green consumption from an organizational perspective. Researchers have observed the effect of environment responsibility from the corporate context (corporate social responsibility) on environmentally friendly consumption behavior (Suganthi, 2019) And research from a consumer perspective is still limited and only started recently. Furthermore, researchers have noted an increasing trend of consumers in developing countries towards the adoption and consumption of green products. For example, in countries such as Malaysia, consumers tend to exhibit proenvironmental behavior by engaging in the eco-friendly goods purchasing habits (Hameed et al., 2019).

In their study on Chinese consumers examined the influence of consumer environment responsibility and green consumption intentions through mediating and moderating mechanisms of environment concern and price sensitivity respectively (Yue et al., 2020). The authors suggest further research replication by introducing new mechanisms that act as a moderator, such as the green products unavailability. Therefore, this study intends to bridge this gap by proposing a mediated moderation model to determine of green product unavailability as moderator variable in the link between consumer environment responsibility, environment concern, and green purchase (consumption) intentions. In addition, the availability of green products can be an effective solution that can help reduce the problem of resource exploitation caused by the increase in global population and unprecedented economic growth especially in developing countries located in the Asian region (Li et al., 2019).

\section{METHODS}

This study uses a causal descriptive design with a case study approach because the researcher wants to describe the relationship of variables to be studied and only focuses on one research object, namely Nutrifood products. The data obtained from this study were collected at one time and did not aim to see changes in data that were influenced by time or commonly referred to as cross sectional (Indrawati, 2015).

In this study, the population is all people who know Nutrifood products in the territory of Indonesia, where the number is not known with certainty. In this case the researcher uses a non-probability sampling method that uses purposive sampling to determine the sample with certain considerations. The sample in this study is people who know Nutrifood products in Indonesia, with the consideration that these people have been looking for Nutrifood products. The reason for these considerations is because in this study there is a moderating variable of green product unavailability, where the availability of Nutrifood products plays an important role in this research instrument. This study will employ 269 respondents as a sample, based on a $95 \%$ confidence level and a $5 \%$ error rate.

SMART PLS 3.2.9 software was used to run the research model, which is Structural Equation Modeling (SEM). Partial Least Squares (PLS) was utilized to analyze the data in this study. Because it focuses more on 
data and with limited estimation procedures, model misspecifications have little effect on parameter estimation. PLS can examine constructs generated using reflexive and formative indicators, which is not feasible with other methods in covariant based SEM because an unidentified model will occur (Ghozali \& Latan, 2015).

Therefore, this study intends to develop a theoretical framework (see Figure 2 in below) from the point of view of TPB (theory of planned behavior) in order to gain a deeper understanding of whether environment responsibility, environment concern and unavailability of green products act as the most important indicators of the inclination to consume green products.

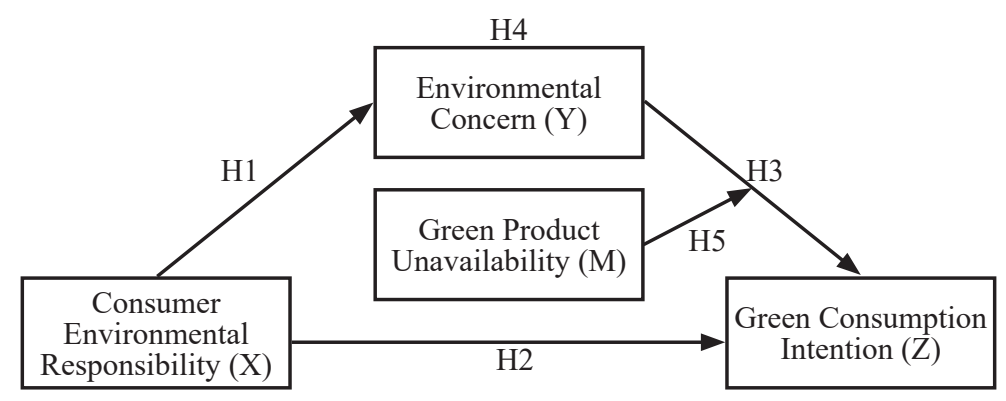

Figure 2. Research Framework Model

\section{RESULTS}

The results of data collection from a sample of 269 respondents were then processed in the SmartPLS software version 3.2.9. In the questionnaires that have been distributed, there are questions that screen prospective respondents (screening questions) to be able to participate in this study, this aims to get optimal results for conclusions of study.

The effect of each indicator and its latent variables was determined using the outer model. It is important to evaluate the reliability and validity of the indicators employed while evaluating the measurement model (outer model). This study's measuring model is depicted in Figure 3.

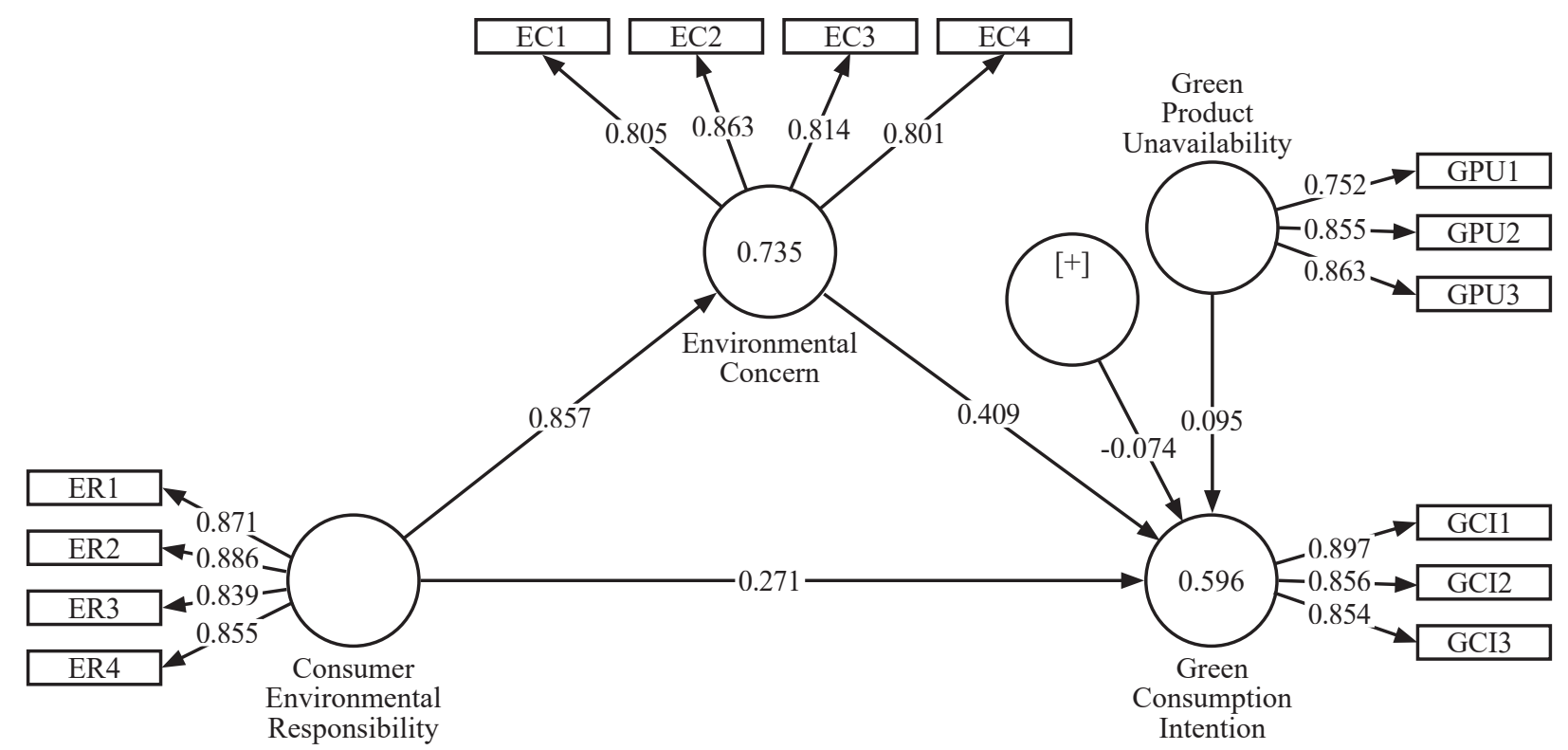

Figure 3. Outer Model of Structural Equation Modelling

The measurement of the outer model is the most significant stage in the evaluation of the measurement model. It deals with component analysis which determines the nature of the proposed relationship. There are two main aspects related to the measurement of the outer model, namely reliability and validity tests. To test the validity, convergent validity and discriminant validity are the two types of tests performed. In addition to validating each variable on SEM-PLS study, a reliability test was also performed, which can be used in two ways, namely composite reliability and Cronbach $\alpha$. Completely perform convergence validity and reliability testing carried out on all of research indicators. 
Table 1. Evaluation of SEM Outer Model Output

\begin{tabular}{|c|c|c|c|c|c|}
\hline & Variable and Indicator & $\begin{array}{c}\text { Outer } \\
\text { Loading }\end{array}$ & $\begin{array}{c}\text { Cronbach } \\
\text { Alpha }\end{array}$ & $\begin{array}{l}\text { Composite } \\
\text { Reliability }\end{array}$ & AVE \\
\hline & Consumer Environment Responsibility (ER) & & 0.886 & 0.921 & 0.745 \\
\hline 1 & ER1: My actions have an impact on environmental health & 0.805 & & & \\
\hline 2 & ER2: I had an ability for protect environment & 0.863 & & & \\
\hline 3 & ER3: I could learn how improve environment & 0.814 & & & \\
\hline \multirow[t]{2}{*}{4} & ER4: I would work to made my surroundings be a better place & 0.801 & & & \\
\hline & Environment Concern (EC) & & 0.839 & 0.892 & 0.674 \\
\hline 5 & EC1: I'm worried about Indonesia's environment quality decrease & 0.871 & & & \\
\hline 6 & EC2: The environment in Indonesia is my main concern & 0.886 & & & \\
\hline 7 & $\begin{array}{l}\text { EC3: I am deeply concerned about the problem of environmental preservation } \\
\text { in Indonesia }\end{array}$ & 0.839 & & & \\
\hline \multirow[t]{2}{*}{8} & $\begin{array}{l}\text { EC4: I regularly consider how Indonesia's environmental quality may be } \\
\text { enhanced }\end{array}$ & 0.855 & & & \\
\hline & Green Consumption Intention (GCI) & & 0.838 & 0.903 & 0.756 \\
\hline 9 & $\begin{array}{l}\text { GCI1: I intend to buy Nutrifood products because of their concern for the } \\
\text { environment }\end{array}$ & 0.897 & & & \\
\hline 10 & $\begin{array}{l}\text { GCI2: Because of their environmental performance, I want to purchase } \\
\text { Nutrifood goods in the future }\end{array}$ & 0.856 & & & \\
\hline \multirow[t]{2}{*}{11} & GCI3: I would be happy to buy Nutrifood products that are eco-friendly & 0.854 & & & \\
\hline & Green Product Unavailability (GPU) & & 0.765 & 0.864 & 0.680 \\
\hline 12 & GPU1: I actually don't know where Nutrifood's products are sold & 0.752 & & & \\
\hline 13 & GPU2: Nutrifood products aren't sold in stores close to my house & 0.855 & & & \\
\hline 14 & GPU3: Unless I look hard enough, I can't locate Nutrifood items & 0.863 & & & \\
\hline
\end{tabular}

We may conclude that all of indicators utilized are valid based on the computation results in Table 1 since the loading factor value was more than 0.5 , allowing us to reach the conclusion that the measurement results have met the feasibility of convergent validity (Ghozali, 2014). As a result, all indicators in the four variables above fulfilled the convergent validity requirements.

In this study, Cronbach's Alpha and Composite Reliability were used to assess the reliability of the model. Each variable must be satisfied in order to be declared as a reliable value, which must be more than 0.60 for Cronbach's alpha, and must be higher than 0.70 for composite reliability (Ghozali, 2014). All of the variables utilized are trustworthy, according to Table 1, since their current values satisfy the criterion, their composite reliability values are more than 0.7 , and their Cronbach alpha values are better than 0.6. Demonstrate that all existing variables are trustworthy, allowing you to test the inner model with any research variable. This indicates that all of the indicators in the questionnaire are consistent when allocated to respondents based on the findings of the field investigation.

Once the reliability of the instrument is confirmed, the next logical step is to measure convergent validity, which assesses the extent to which the constructs have a theoretical relationship with each other. AVE is used to measure the degree of convergence between constructs. The acceptable threshold value for AVE is more than 0.50. The Table 1 illustrates that all AVE values exceed the minimum AVE threshold value. The range of AVE values is between 0.674 and 0.756 Therefore, presence of convergent validity is confirmed.

The degree to which one construct differs and is distinct from another is referred to as discriminant validity. The most widely used in assessing discriminant validity is Fornell-Larcker criterion (Table 2).

Table 2. Evaluation of Discriminant Validity

\begin{tabular}{ccccc}
\hline & ER & EC & GCI & GPU \\
\hline ER & 0.863 & & & \\
EC & 0.757 & 0.821 & & \\
GCI & 0.726 & 0.749 & 0.869 & \\
GPU & 0.740 & 0.764 & 0.634 & 0.825 \\
\hline
\end{tabular}


It is claimed that discriminant validity has been proven when the square root of the AVE obtained for each construct is greater than the greatest correlation of the construct with other latent constructs. The table above describes the results of the Fornell-Larcker method used to measure discriminant validity. The square root of the AVE of a construct depicted in bold is higher than its greatest correlation with other constructs, as can be observed. (Ghozali, 2014). Thus it can be ascertained that discriminant validity has been established. Thus, after the calculations have been carried out, all of the indicators in this study have been certified as legitimate (valid), which means that they are based on field analysis results, all indicators of questions in the questionnaire are suitable to be used as measuring tools.

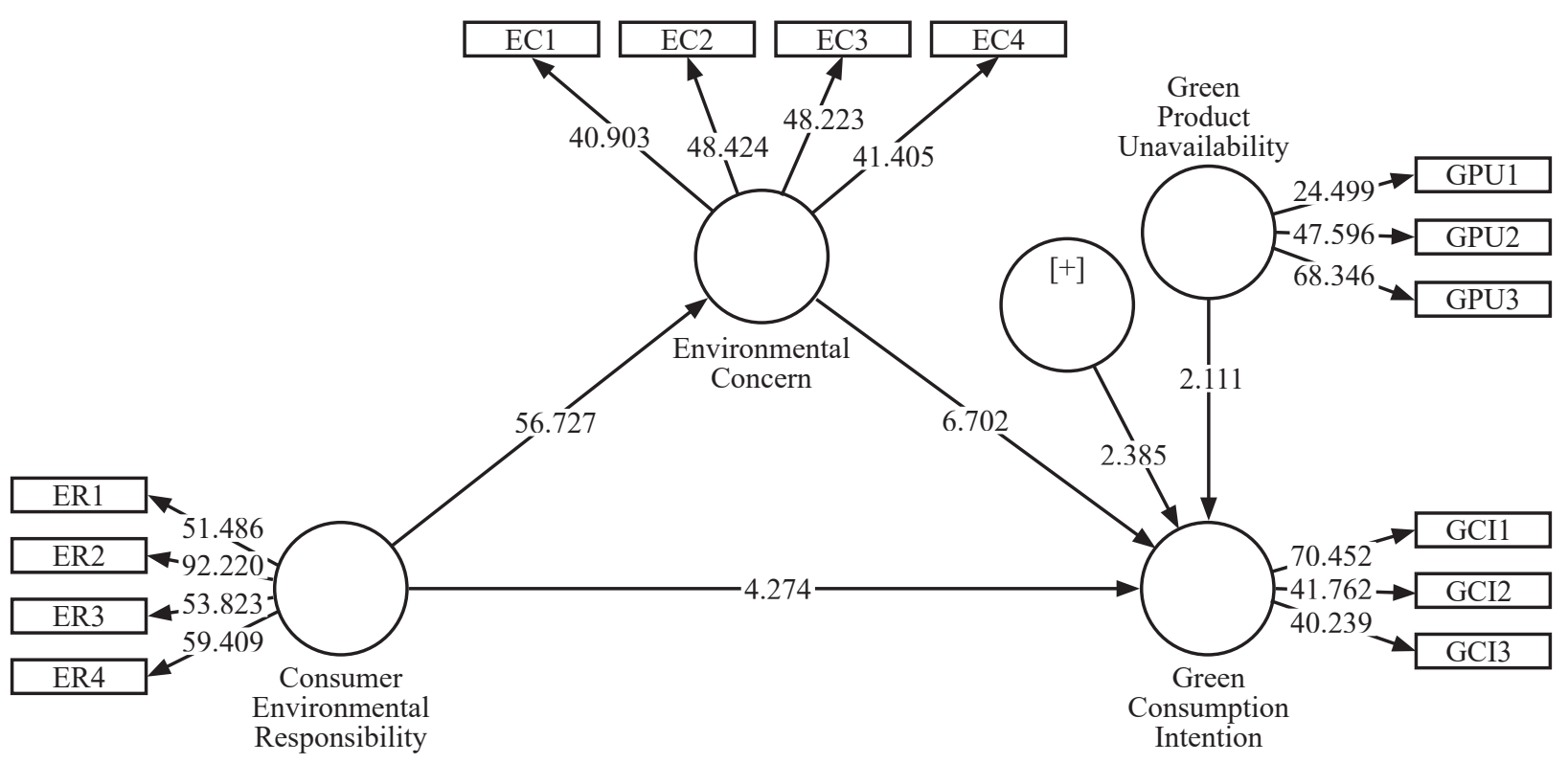

Figure 4. Inner Model of Structural Equation Modelling

The inner model test (also called inner relation or structural model) is aims to determine the influence of the constructs, and the importance and value of the R-squared of the research model being conducted, while considering the value R-square on the endogenous latent variable and the value of t-count on any exogenous latent variables in the endogenous latent variable from the result of bootstrapping process. The next process is to see whether there is a significant and strong influence of the independent and dependent variable. The inner model's route design is depicted in Figure 4. The t statistics of each exogenous to endogenous latent variable may be viewed. This research use a one-tailed test with 5\% error rate to test the hypothesis. Then the critical value to be reached in this hypothesis test is 1.6506 . If the t-statistic value is greater than the critical value (1.6506), then there is a significant influence between the exogenous and endogenous latent variable, which can be observed in the Table 3 .

Table 3. Evaluation of SEM Inner Model Output

\begin{tabular}{llccccr}
\hline \multicolumn{1}{c}{ Hypothesis/Path } & $\begin{array}{c}\text { Path } \\
\text { Coefficient }\end{array}$ & $\begin{array}{c}\text { Standard } \\
\text { Deviation }\end{array}$ & t-Statistics & P Values & Decision \\
\hline H1 & $\begin{array}{l}\text { Environment Responsibility to Environment } \\
\text { Concern }\end{array}$ & 0.857 & 0.013 & 66.727 & 0.000 & H1 Accepted \\
H2 & $\begin{array}{l}\text { Environment Responsibility to Green } \\
\text { Consumption Intention }\end{array}$ & 0.271 & 0.063 & 4.274 & 0.000 & H2 Accepted \\
H3 $\begin{array}{l}\text { Environment Concern to Green Consumption } \\
\text { Intention }\end{array}$ & 0.409 & 0.061 & 6.702 & 0.000 & H3 Accepted \\
H4 $\begin{array}{l}\text { Environment Responsibility to Green } \\
\text { Consumption Intention through Environment } \\
\text { Concern }\end{array}$ & 0.351 & 0.053 & 6.677 & 0.000 & H4 Accepted \\
Hoderating role of Green Product Unavailability & -0.074 & 0.031 & 2.111 & 0.009 & H5 Accepted \\
in Environment Concern to Green Consumption \\
Intention
\end{tabular}




\section{DISCUSSIONS}

This section will discuss the research result from the previous section. The analysis for the results will be focused on the impact oow growth of income per capita and small change in income inequality.

The results of the direct relationship based on the bootstrap technique and the PLS-SEM algorithm have been shown in Table 3 above. After a thorough review of the model path coefficients in the outer model, it can be assessed by examining the t-statistical values in the outer load (ie, path coefficient, standard deviation, $\mathrm{t}$-statistic value, and $\mathrm{P}$ values). The path coefficient depicts the direction of each variable's effect. If it is positive, it means that the influence of each variable is positive and vice versa. Then $\mathrm{t}$-statistic value and $\mathrm{P}$-value indicate the significance level of relationship, if the t-count value is above 1.6506, then the influence of each variable is significant. Other consideration is when the $p$-value is less than 0.05 , the link between the variables is considered significant. The table above illustrates that all t-statistic values are greater than the acceptable threshold of 1.6506 and the P-value has been smaller than 0.05 .

The value of R-square on the environment concern variable means that exogenous variables (consumer environment responsibility) affect the endogenous variable by 0.735 or $73.5 \%$ and the rest is $26.5 \%$ influenced by other factors not examined. Then the value of R-square on the green consumption intention variable means that the exogenous consumer environment responsibility variable and the mediator environment concern variable affect the endogenous green consumption intention variable by 0.596 or $59.6 \%$ and the rest $40.4 \%$ is impacted by additional variables that have not been investigated. On the assessment criteria using PLS, the R-square value of 0.67 denotes a 'excellent' model, 0.33 a 'moderate' model, and 0.19 a 'weak' model (Ghozali, 2014). This study resulted in an R-square value of 0.735 for environment concern and 0.596 for green consumption intention which indicates that the model in this study is good and moderate.

The underlying objective of this research is to look at the direct effect of environmental responsibility on green consumption intentions. In addition, the indirect impact of these variables through the mediating role of environment concern is also analyzed. In addition, the function of green product unavailability as a moderator in the connection between environment concern and green consumption intentions was also examined. A total of five hypotheses were developed based on the findings mentioned in the existing literature. This hypothesis is observed by way of the TPB (theory planned behavior). This section presents a thorough discussion of this hypothesis in relation to the existing research.

First hypothesis declare that environment responsibility has a positive and significant impact on environment concern. This theory is supported by the research findings. This indicates that there was a positive effect of consumer environment responsibility on concern for the environment. Therefore, it can be concluded that an increase in individual environment responsibility will resulting in a substantial (significant) rise in development of environment concern. This is as done in previous studies which showed a strong influence of environment responsibility and concern for the environment (Sadachar et al., 2016; Slavoljub et al., 2015; White \& Simpson, 2013; Yue et al., 2020). For example, (Chuang \& Huang, 2018) observed that individuals with a stronger sense of environment responsibility are more concerned about environmental issues and advocate for the usage and adoption of green products because they believe humans are solely to blame for the emergence of various environmental problems. Given these findings, it can be said that a higher sense of environment responsibility leads to the development of a sense of environment concern.

Second hypothesis stated that environment responsibility has a positive and significant influence on green consumption intention. The research results support this hypothesis. The existence of a positive relationship means that with increasing consumer environment responsibility, the tendency to develop green consumption intentions will also increase. This finding is fully in accordance with prior research findings. As example, (Attaran \& Celik, 2015) commissioned a research to assess the impact of environment responsibility on green consumption behavior. The results reveal that environmentally responsible individuals show a greater tendency to develop green consumption intentions which in turn makes them describe green consumption behaviors such as buying green products. This is as done in previous studies showing a positive influence of environment responsibility and green consumption intentions that have been examined in various cultural contexts (Attaran \& Celik, 2015; Slavoljub et al., 2015; Wu \& Yang, 2018; Xu et al., 2020). Therefore, the premise in this investigation is that there is a significant and positive influence of environment responsibility and green consumption intentions. This means that environment responsibility is an individual's obligation if he is willing to make efforts to overcome environmental problems at a personal level.

Then the third hypothesis argued that environment concern has a significant and positive impact on the inclination to consume green products. The results support this hypothesis. This means that environment concern and green consumption intentions are positively related to each other. In other terms, an increase in consumer environment concern will result in a considerable and tangible increase on the development of green consumption 
intentions. This discovery backs up the findings of previous studies carried out in same but different cultural contexts. For example, (Suki, 2016) suggests that individuals who care more about their environment tend to develop pro-environmental attitudes which in turn encourage them to develop green consumption intentions. This is as done in previous studies which showed that environment concern has a direct and positive relationship with green consumption intentions (McDonald et al., 2015; Suki, 2016; Xu et al., 2020). Therefore, consumers who have a higher sense of environment concern show more willingness to engage in green consumption behavior by paying for environmentally friendly products and services.

The fourth hypothesis was environment responsibility has a significant and positive influence in created green consumption intention through environment concern mediation. The results confirm the indirect effect of environment responsibility on green consumption intentions through environment concern. This means that environment concern mediates the relationship between environment responsibility and green consumption intentions. This conclusion is consistent with prior research findings which also confirmed the mediating role of environment concern in the same context. For example, (Tsarenko et al., 2013) observed that environment responsibility passes through environment concerns before influencing individual green consumption behavior. This is as done in previous studies which showed that environment responsibility positively influences proenvironmental behavior such as green consumption intentions, through the mediating role of the environment (Rahimah et al., 2018; Tsarenko et al., 2013; Yue et al., 2020). Therefore, it is certain that environment concern is an important construct that helps illustrate how environment responsibility building has an indirect impact on green consumption.

The last hypothesis is green product unavailability plays a moderate role in the influence of environment concern and green consumption intention. The results support this hypothesis. This means that the unavailability of green products moderates the influence of environment concern and green consumption intentions negatively. In other words, the unavailability of green products will weaken the influence of environment concern and green consumption intentions. This is as done in previous studies which showed that the availability of green products is the primary motivator for customers to engage and develop green consumption intention. Where the availability of green products encourages consumers to be willing to buy and buy green items or goods (Gottschalk \& Leistner, 2013; Shahnaei, 2012; Shi et al., 2017; Walia et al., 2020; Wang et al., 2016). The unavailability of green products encourages consumers to buy other conventional products that can pose certain risks to the environment. However, there are major obstacles that hinder the activation of green consumption behavior among environmentally responsible consumers. This barrier is mainly due to the unavailability of green products in the consumer market. Environment responsibility and concern cannot be turned into behavior unless there are substitutes for green products available in the market that will suppress the demand for conventional products.

The availability of green products is one of the main antecedents that drive consumers to develop green purchase intentions. However, despite the increased awareness, consumers are still less informed about ecofriendly products and their features and attributes. Before authors suggest further research replication by introducing new mechanisms that act as a moderator, such as the unavailability of green product. Therefore, this study intends to bridge this gap by evaluate the moderating impact of green product unavailability in the link between environment responsibility, environment concern, and green consumption intention, researchers used a mediated moderation model.

This study strengthens the literature on the connection between consumer environment responsibility, environment concern and green consumption intentions from the perspective of individual consumers. Although there is a lot of literature available which focuses about the influence of environment responsibility and green consumption intentions but mostly examines this relationship through the lens of corporate environment responsibility. In addition, this study reveals that concern for the environment is an important precursor and bridge that helps encourage the development of green consumption intentions. This finding is consistent with several existing studies considering the unavailability of green products as an important antecedent that plays an important role towards the development of green consumption intentions.

\section{CONCLUSIONS}

The findings of this study indicate that consumer environment responsibility, environment concern and green consumption intentions have a positive and significant influence, which showed that environmental concern is an important mediating variable in the interplay between environment responsibility and green consumption intentions. Then this study makes a valuable contribution to the existing literature by examining the function of green product scarcity as a moderator has negative effect from environment concern to green consumption intentions significantly.

Nutrifood companies are advised to consistently produce green innovative products, because it can increase 
consumer environment responsibility and concern about environment. If consumer confidence with company's green product produced was increased, the consumption of purchasing green products will also increase. Therefore, it becomes imperative for management of Nutrifood to make collective efforts aimed at acquiring and adopting pro-environmental values and knowledge to develop environmental awareness and engage in changing consumption patterns to promote green consumption behavior. For further research, it is recommended to carry on with the study, but with the addition of factor variables relating to green marketing. Then further researchers are advised to examine companies that are similar to this research, so that later the results of the research can be used as a comparative study.

\section{REFERENCES}

Alam, S. S., Lin, C. Y., Ahmad, M., Omar, N. A., \& Ali, M. H. 2019. Factors Affecting Energy-efficient Household Products Buying Intention: Empirical Study. Environmental and Climate Technologies, 23(1), 84-97. https:// doi.org/10.2478/rtuect-2019-0006

Apollo. 2021. Nutrifood-Overview. http://www.apollo.io/companies/Nutrifood/5569452f7369642105862300 ?chart=count/

Attaran, S., \& Celik, B. G. 2015. Students' Environmental Responsibility and Their Willingness to Pay for Green Buildings. International Journal of Sustainability in Higher Education, 16(3), 327-340. https://doi. org/10.1108/IJSHE-04-2013-0029

Awuni, J. A., Du, J., \& Yiranbon, E. 2016. Factors Influencing Green Purchasing Behaviors: Some Insights from Tamale, Ghana. British Journal of Economics, Management \& Trade, 14(4), 1-12. https://doi.org/10.9734/ bjemt/2016/27676

Chen, A., \& Peng, N. 2012. Green Hotel Knowledge and Tourists' Staying Behavior. Annals of Tourism Research, 39(4), 2211-2219. https://doi.org/10.1016/j.annals.2012.07.003

Chen, C. C., Chen, C. W., \& Tung, Y. C. 2018. Exploring the Consumer Behavior of Intention to Purchase Green Products in Belt and Road Countries: An Empirical Analysis. Sustainability (Switzerland), 10(3), 854 (1-16). https://doi.org/10.3390/su10030854

Chen, M. F., \& Tung, P. J. 2014. Developing an Extended Theory of Planned Behavior Model to Predict Consumers' Intention to Visit Green Hotels. International Journal of Hospitality Management, 36, 221-230. https://doi.org/10.1016/j.ijhm.2013.09.006

Chen, Y. S., Lin, C. Y., \& Weng, C. S. 2015. The Influence of Environmental Friendliness on Green Trust: The Mediation Effects of Green Satisfaction and Green Perceived Quality. Sustainability (Switzerland), 7(8), 10135-10152. https://doi.org/10.3390/su70810135

Chuang, S. P., \& Huang, S. J. 2018. The Effect of Environmental Corporate Social Responsibility on Environmental Performance and Business Competitiveness: The Mediation of Green Information Technology Capital. Journal of Business Ethics, 150(4), 991-1009. https://doi.org/10.1007/s10551-016-3167-x

Copernicus Climate Change Service. 2021. Copernicus: 2020 Warmest Year on Record for Europe; Globally, 2020 ties with 2016 for Warmest Year Recorded. Press Release. https://climate.copernicus.eu/copernicus2020-warmest-year-record-europe-globally-2020-ties-2016-warmest-year-recorded

Dagher, G. K., Itani, O., \& Kassar, A. N. 2015. The Impact of Environment Concern and Attitude on Green Purchasing Behavior: Gender as The Moderator. Contemporary Management Research, 11(2), 179-206. https://doi.org/10.7903/cmr.13625

Ghozali, I. 2014. Structural Equation Modeling, Metode Alternatif Dengan Partial Least Square (PLS), Dilengkapi Software Smartpls 3.0, Xlstat 2014, dan WarpPLS 4.0. In Semarang: Badan Penerbit Universitas Diponegoro (4th ed.).

Ghozali, I., \& Latan, H. 2015. Partial Least Squares: Konsep, Teknik dan Aplikasi Menggunakan Program SmartPLS 3.0. In Semarang: Badan Penerbit Undip.

Gottschalk, I., \& Leistner, T. 2013. Consumer Reactions to the Availability of Organic Food in Discount Supermarkets. International Journal of Consumer Studies, 37(2), 136-142. https://doi.org/10.1111/j.14706431.2012.01101.x

Hameed, I., Waris, I., \& Amin ul Haq, M. 2019. Predicting Eco-conscious Consumer Behavior Using Theory of Planned Behavior in Pakistan. Environmental Science and Pollution Research, 26(15), 15535-15547. https://doi.org/10.1007/s11356-019-04967-9

Hojnik, J., Ruzzier, M., \& Ruzzier, M. K. 2019. Transition Towards Sustainability: Adoption of Eco-products Among Consumers. Sustainability (Switzerland), 11(16), 4308 (1-29). https://doi.org/10.3390/su11164308

Indrawati. 2015. Metode Penelitian Manajemen dan Bisnis Konvergensi Teknologi Komunikasi dan Informasi. In Bandung: PT Refika Aditama. 
Jambeck, J. R., Geyer, R., Wilcox, C., Siegler, T. R., Perryman, M., Andrady, A., Narayan, R., \& Law, K. L. 2015. Plastic Waste Inputs from Land into the Ocean. Science, 347(6223), 768-771. https://doi.org/10.1126/ science. 1260352

Kautish, P., Paul, J., \& Sharma, R. 2019. The Moderating Influence of Environmental Consciousness and Recycling Intentions on Green Purchase Behavior. Journal of Cleaner Production, 228, 1425-1436. https:// doi.org/10.1016/j.jclepro.2019.04.389

Khaola, P., Potiane, B., \& Mokhethi, M. 2014. Environmental Concern, Attitude Towards Green Products and Green Purchase Intentions of Consumers in Lesotho. Ethiopian Journal of Environmental Studies and Management, 7(4), 361-370. https://doi.org/10.4314/ejesm.v7i4.3

Klöckner, C. A., Nayum, A., \& Mehmetoglu, M. 2013. Positive and Negative Spillover Effects from Electric Car Purchase to Car Use. Transportation Research Part D: Transport and Environment, 21(8), 32-38. https:// doi.org/10.1016/j.trd.2013.02.007

Li, X., Du, J., \& Long, H. 2019. Theoretical Framework and Formation Mechanism of the Green Development System Model in China. Environmental Development, 32(100465), 1-13. https://doi.org/10.1016/j. envdev.2019.100465

Lutfie, H., \& Marcelino, D. 2020. Consumer Trust to Buy Green Product: Investigation of Green Perceived Value with Green Satisfaction Mediation. 2020 8th International Conference on Cyber and IT Service Management, CITSM 2020, 1-6. https://doi.org/10.1109/CITSM50537.2020.9268826

Marcelino, D. 2020. Green Purchase Intention Pada Konsumen Nutrifood di Bandung: Peran Environment Concern Dengan Mediasi Green Trust. Jurnal Sekretaris \& Administrasi Bisnis (JSAB), 4(1), 01. https:// doi.org/10.31104/jsab.v4i1.152

McDonald, S., Oates, C. J., Thyne, M., Timmis, A. J., \& Carlile, C. 2015. Flying in the Face of Environmental Concern: Why Green Consumers Continue to Fly. Journal of Marketing Management, 31(13-14), 1503-1528. https://doi.org/10.1080/0267257X.2015.1059352

Moravcikova, D., Krizanova, A., Kliestikova, J., \& Rypakova, M. 2017. Green Marketing as the Source of the Competitive Advantage of the Business. Sustainability (Switzerland), 9(12), 2218 (1-13). https://doi. org/10.3390/su9122218

Nilasari, N., \& Kusumadewi, M. 2016. Peran Sikap dalam Memediasi Pengaruh Kepedulian Lingkungan Terhadap Niat Beli Kosmetik Hijau Merek the Body Shop. None, 5(2), 821-848. https://ojs.unud.ac.id/ index.php/Manajemen/article/view/15942

Ogiemwonyi, O., Harun, A. Bin, Othman, B. A., Ismael, D. A., \& Ali, R. 2019. Key Issues and Challenges of Green Consumer in Consuming Green Product an Insight from the Emerging Country: Malaysia. International Journal of Psychosocial Rehabilitation, 23(2), 514-528. https://doi.org/10.37200/IJPR/V23I2/PR190313

Pambudi, T. S. 2018. Adu Inisiatif di Jalur Hijau dalam Majalah SWA Edisi XXXIV Indonesia Green Companies 2018. Jakarta: PT Swasembada Media Bisnis.

Rahimah, A., Khalil, S., Cheng, J. M. S., Tran, M. D., \& Panwar, V. 2018. Understanding Green Purchase Behavior through Death Anxiety and Individual Social Responsibility: Mastery as a moderator. Journal of Consumer Behaviour, 17(5), 477-490. https://doi.org/10.1002/cb.1733

Ru, X., Wang, S., Chen, Q., \& Yan, S. 2018. Exploring the Interaction Effects of Norms and Attitudes on Green Travel Intention: An empirical study in Eastern China. Journal of Cleaner Production, 197, 1317-1327. https://doi.org/10.1016/j.jclepro.2018.06.293

Sadachar, A., Feng, F., Karpova, E. E., \& Manchiraju, S. 2016. Predicting Environmentally Responsible Apparel Consumption Behavior of Future Apparel Industry Professionals: The Role of Environmental Apparel Knowledge, Environmentalism and Materialism. Journal of Global Fashion Marketing, 7(2), 76-88. https:// doi.org/10.1080/20932685.2015.1131433

Shabani, N., Ashoori, M., Taghinejad, M., Beyrami, H., \& Fekri, M. N. 2013. The Study of Green Consumers' Characteristics and Available Green Sectors in the Market. International Research Journal of Applied and Basic Sciences, 44(7), 1880-1883. https://irjabs.com/files_site/paperlist/r_925_130610221654.pdf

Shahnaei, S. 2012. The Impact of Individual Differences on Green Purchasing of Malaysian Consumers. International Journal of Business and Social Science, 3(16), 132-141. https://ijbssnet.com/journals/Vol_3_ No_16_Special_Issue_August_2012/14.pdf

Shi, H., Wang, S., \& Zhao, D. 2017. Exploring Urban Resident's Vehicular PM2.5 Reduction Behavior Intention: An Application of the Extended Theory of Planned Behavior. Journal of Cleaner Production, 147, 603-613. https://doi.org/10.1016/j.jclepro.2017.01.108

Slavoljub, J., Zivkovic, L., Sladjana, A., Dragica, G., \& Zorica, P. S. 2015. To the Environmental Responsibility among Students through Developing their Environmental Values. Procedia - Social and Behavioral Sciences, 171,317-322. https://doi.org/10.1016/j.sbspro.2015.01.128 
Sreen, N., Purbey, S., \& Sadarangani, P. 2018. Impact of Culture, Behavior and Gender on Green Purchase Intention. Journal of Retailing and Consumer Services, 41, 177-189. https://doi.org/10.1016/j.jretconser.2017.12.002

Suganthi, L. 2019. Examining the Influence of Corporate Social Responsibility, Performance, Employees' Proenvironmental Behavior at Work with Green Practices as Mediator. Journal of Cleaner Production, 232, 739-750. https://doi.org/10.1016/j.jclepro.2019.05.295

Suki, N. M. 2016. Consumer Environmental Concern and Green Product Purchase in Malaysia: Structural Effects of Consumption Values. Journal of Cleaner Production, 132, 202-214. https://doi.org/10.1016/j. jclepro.2015.09.087

Ting, D. H., \& Cheng, C. F. C. 2017. Measuring the Marginal Effect of Pro-environmental Behaviour: Guided Learning and Behavioural Enhancement. Journal of Hospitality, Leisure, Sport and Tourism Education, 20, 16-26. https://doi.org/10.1016/j.jhlste.2016.12.001

Tsarenko, Y., Ferraro, C., Sands, S., \& McLeod, C. 2013. Environmentally Conscious Consumption: The Role of Retailers and Peers as External Influences. Journal of Retailing and Consumer Services, 20(3), 302-310. https://doi.org/10.1016/j.jretconser.2013.01.006

Walia, S. B., Kumar, H., \& Negi, N. 2020. Impact of Brand Consciousness, Perceived Quality of Products, Price Sensitivity and Product Availability on Purchase Intention Towards Green Products. International Journal of Technology Management and Sustainable Development, 19(1), 107-118. https://doi.org/10.1386/ tmsd 000181

Wang, S., Fan, J., Zhao, D., Yang, S., \& Fu, Y. 2016. Predicting Consumers' Intention to Adopt Hybrid Electric Vehicles: Using an Extended Version of the Theory of Planned Behavior Model. Transportation, 43(1), 123-143. https://doi.org/10.1007/s11116-014-9567-9

White, K., \& Simpson, B. 2013. When Do (and don't) Normative Appeals Influence Sustainable Consumer Behaviors. Journal of Marketing, 77(2), 78-95. https://doi.org/10.1509/jm.11.0278

Wu, B., \& Yang, Z. 2018. The Impact of Moral Identity on Consumers' Green Consumption Tendency: The Role of Perceived Responsibility for Environmental Damage. Journal of Environmental Psychology, 59, 74-84. https://doi.org/10.1016/j.jenvp.2018.08.011

Xu, X., Hua, Y., Wang, S., \& Xu, G. 2020. Determinants of Consumer's Intention to Purchase Authentic Green Furniture. Resources, Conservation and Recycling, 156(104721), 1-8. https://doi.org/10.1016/j. resconrec.2020.104721

Yen, G. F., Wang, R. Y., \& Yang, H. T. 2017. How Consumer Mindsets in Ethnic Chinese Societies Affect the Intention to Buy Fair Trade Products: The Mediating and Moderating Roles of Moral Identity. Asia Pacific Journal of Marketing and Logistics, 29(3), 553-568. https://doi.org/10.1108/APJML-06-2016-0107

Yue, B., Sheng, G., She, S., \& Xu, J. 2020. Impact of Consumer Environmental Responsibility on Green Consumption Behavior in China: The Role of Environmental Concern and Price Sensitivity. Sustainability (Switzerland), 12(5), 2074 (1-16). https://doi.org/10.3390/su12052074

Zheng, Y., \& Chi, T. 2015. Factors Influencing Purchase Intention towards Environmentally Friendly Apparel: An Empirical Study of US Consumers. International Journal of Fashion Design, Technology and Education, 8(2), 68-77. https://doi.org/10.1080/17543266.2014.990059

Zhou, Y., Thøgersen, J., Ruan, Y., \& Huang, G. 2013. The Moderating Role of Human Values in Planned Behavior: The Case of Chinese Consumers' Intention to Buy Organic Food. Journal of Consumer Marketing, 30(4), 335-344. https://doi.org/10.1108/JCM-02-2013-0482

Zokaei, K., Lovins, H., Wood, Y., \& Hines, P. 2013. Lean and Green Business Process Management. In Creating a Lean and Green Business System (pp. 65-100). Productivity Press. https://doi.org/10.1201/b14874-7 